ОРИГИНАЛНИ НАУЧНИ РАДОВИ

ОРИГИНАЛЬНЫЕ НАУЧНЫЕ СТАТЬИ

ORIGINAL SCIENTIFIC PAPERS

\title{
THE SECOND COVID-19 WAVE OF 2020 IN ITALY: A BRIEF ANALYSIS
}

\author{
Nicola Fabiano ${ }^{a}$, Stojan N. Radenovićb \\ a Independent researcher, Rome, Italy, \\ e-mail: nicola.fabiano@gmail.com, corresponding author, \\ ORCID iD: (1) https://orcid.org/0000-0003-1645-2071 \\ ${ }^{b}$ University of Belgrade, Faculty of Mechanical Engineering, \\ Belgrade, Republic of Serbia, \\ email: radens@beotel.rs, \\ ORCID iD: @ https://orcid.org/0000-0001-8254-6688
}

DOI: 10.5937/vojtehg69-29511; https://doi.org/10.5937/vojtehg69-29511

FIELD: Mathematics

ARTICLE TYPE: Original scientific paper

Abstract:

Introduction/purpose: Based on the results obtained previously, the second wave of Covid-19 infection is analyzed and some predictions on its evolution are given.

Methods: A model of population growth giving a differential equation has been used to describe the pandemic wave.

Results: The second wave of infection is essentially on its peak in the middle of November 2020 and will not decrease very soon.

Conclusions: The second wave is not going to end in the year 2020 and it will take some time before a status of relative normality is restored.

Key words: Coronavirus, COVID-19, differential equation, data fit.

\section{Equation and Fit}

The equation we have used in the model of Covid-19 evolution of a number of cases in time (Verhults, 1838) is given by (Fabiano \& Radenović, 2020a)

$$
\frac{d x(t)}{d t}=\frac{x(t)}{a}\left[1-\frac{x(t)}{b}\right],
$$

where the total number of cases $x(t)$ at a given time is given by 


$$
x(t)=\frac{c}{1+\exp [(b-t) / a]},
$$

while the growth of cases is given by its derivative

$$
\frac{d x(t)}{d t}=\frac{c}{a}\left\{\frac{\exp [(b-t) / a]}{(1+\exp [(b-t) / a])^{2}}\right\} .
$$

The parameter $a$ is related to the growth rapidity, $c$ is the asymptotic total number of cases, and $b$ indicates the peak position of the growth of cases.

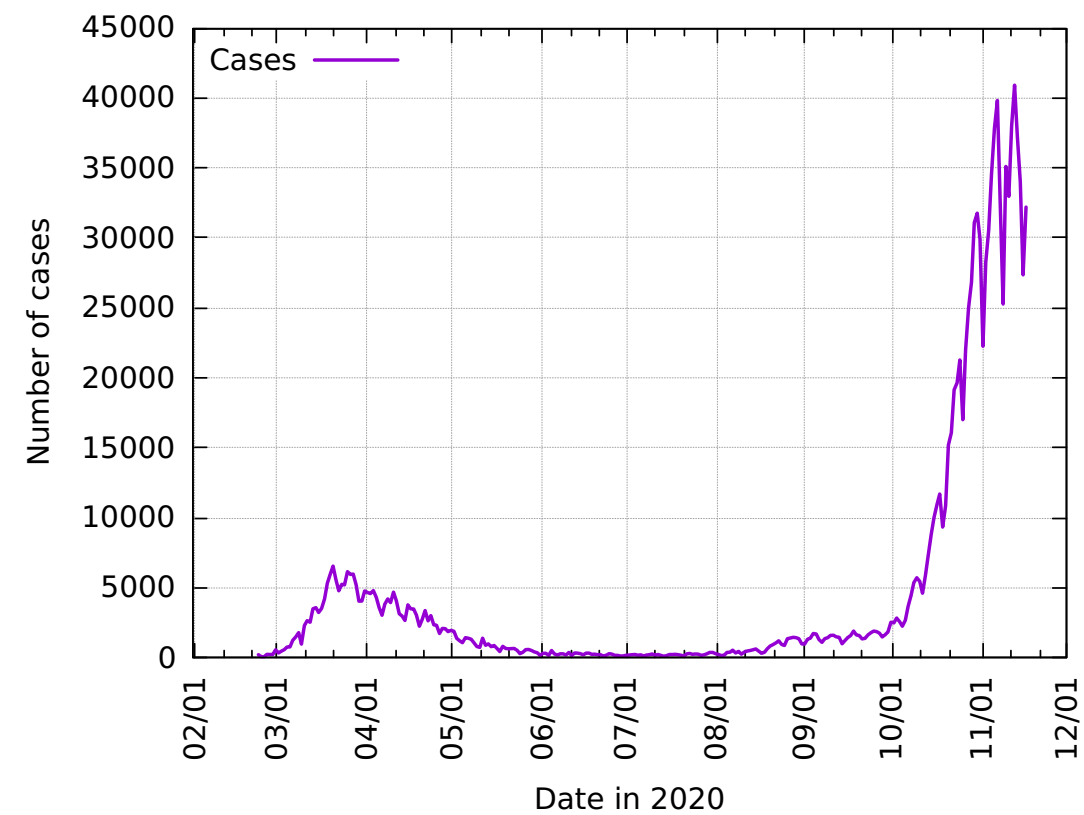

Figure 1 - Number of new cases of coronavirus per day with respect to the date for the year 2020

Pис.1 - Количество новых случаев зараженных коронавирусом за сутки по датам в 2020 году

Слика 1 - Број нових случајева заражених вирусом корона дневно у односу на датуме 2020. године

Figure 1 shows the number of new cases per day of coronavirus in Italy with respect to the date. One can clearly see two peaks corresponding to two different waves of the disease, the first with a maximum of around 6000 
cases on the $26^{\text {th }}$ of March, and the second one with around 40000 cases on the $13^{\text {th }}$ of November.

In (Fabiano \& Radenović, 2020b) we have compared the current coronavirus pandemic to the influenza pandemic of 1918 and gave some predictions on the possible future waves. Notably, in accordance with the data of 1918, it has been predicted in Table 5 of the above mentioned article that the second wave of the pandemic would have a peak number of new cases per day that has a fivefold increase of the peak of the first wave. According to the above mentioned data the accuracy of this prediction is astonishingly good.

In order to determine the parameters $a, b, c$ of equations 1, 2, 3 for the second wave, we have done a fit to the most recent data available for the coronavirus disease in Italy, available at the GitHub account (Ministero della Salute, 2020).

The minimum value of new cases has been encountered on the $14^{\text {th }}$ of July with 114 new patients on that day. This will be the starting point of the second peak. The results of the fit are shown in Table 1.

Table 1 - Fit for the parameters $a, b, c$ of the second wave

Таблица 1 - Распределение по параметрам $a, b, c$ во второй волне Табела 1 - Поклапање параметара a, b и с другог таласа

\begin{tabular}{|c|c|c|c|}
\hline Parameter & Value & Error & Error \% \\
\hline$a$ & 9.88343 & 0.332 & 3.359 \\
\hline$b$ & 119.106 & 0.558 & 0.4685 \\
\hline$c$ & $1.40299 \times 10^{6}$ & $4.605 \times 10^{4}$ & 3.282 \\
\hline
\end{tabular}

The maximum of the peak is obtained from the value of $c /(4 a)$, the parameters $a$ and $c$ are linked respectively to the height and width of the bellshaped function of equation 3 , while $b$ traslates in time the position of the peak.

As expected, the values of the parameters are much bigger than the one found in Table 1 of (Fabiano \& Radenović, 2020a), because the peak of the second wave is much larger as discussed above, and the rise of the peak is much sharper than the one of the first wave. Observe also that according to the value of $c$ obtained, the total number of cases so far is expected to be not less than 1.4 million, more than $2 \%$ of the population.

Figure 2 shows the data of the second wave and the fit to the function 3 with respect to the number of days since the $14^{\text {th }}$ of July. The fit is prolonged 


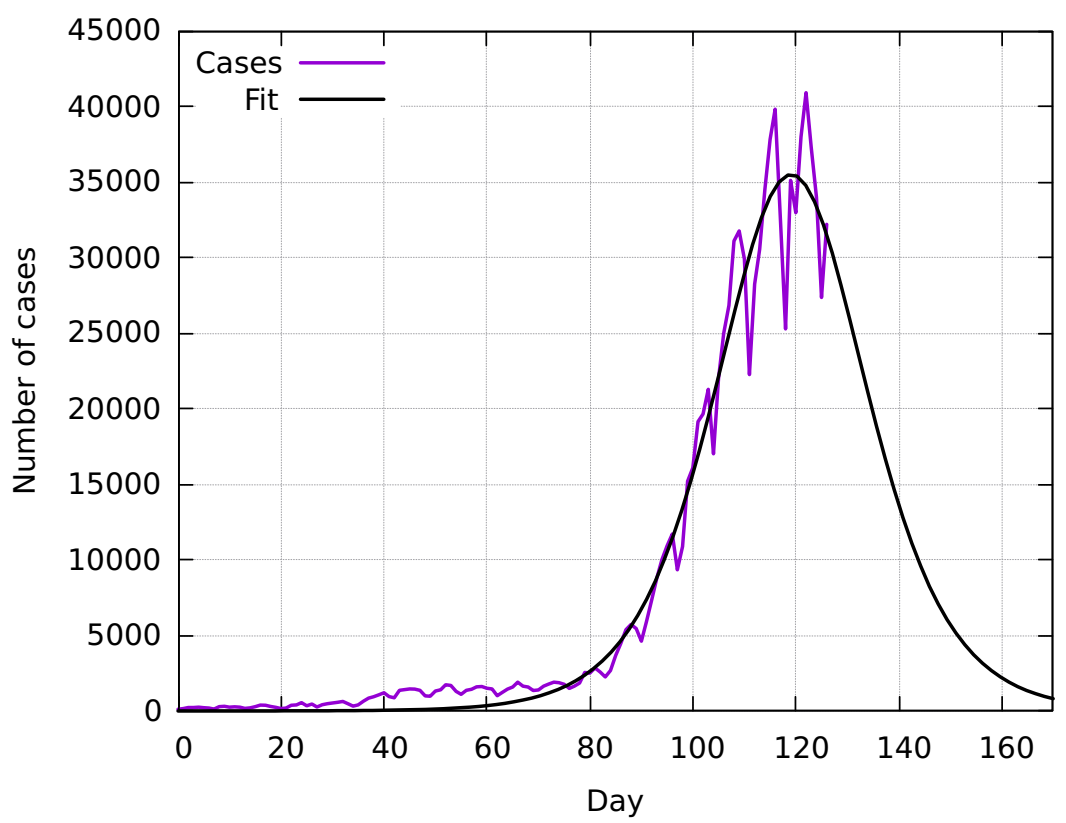

Figure 2 - Number of new cases of coronavirus per day with respect to the numbers of days starting from the $14^{\text {th }}$ of July 2020 and ending on $31^{\text {st }}$ of

December 2020

Pис. 2 - Количество новых случаев зараженных коронавирусом за сутки с 14 июля 2020 г. по 31 декабря 2020 года

Слика 2 - Број нових случајева заражених вирусом корона по дану у односу на број дана почевши од 14. јула 2020. године и закључно са 31. децембром 2020. године

beyond the current date of $17^{\text {th }}$ of November, that is 127 days in order to give some insight of the future situation.

The bell-shaped curve is symmetric around the peak, therefore a quick raise provides also a fast decline of the number of cases, albeit with a caveat that will be discussed later on.

The limit of 5000 new cases per day is crossed again on the 152th day, i.e. around the half of December. On the last day of 2020 , i.e. on the 170th day, there will still be more than 800 cases per day, resembling the same situation already encountered in May. Depending on how many new cases per day is considered acceptable, we will not reach again a "normal" status before the half of January 2021. 
Yet there is a caveat. Considering again the global situation in Figure 1 and carefully observing the first peak, it is clear that it is not completely symmetric, having a decreasing side lasting longer than the increasing one. This is probably due to the fact that the quarantine rules employed are not static in time, and are progressively relaxed, as the pandemic situation turns better, for various reasons, mainly due to the concern about the worsening of the economic situation. It is also worth mentioning the fact that a part of the population tends not to abide by the quarantine rules after a longer period of time, as it has been observed particularly in the past summer when the pandemic was considered ended by many sources, some of them apparently respectable.

\section{Conclusion}

Cosidering all the reasons discussed before it is reasonable to conclude that the obtained fit given for equation 3 and shown in Figure 2 is actually an estimate from below for the return time to a normal situation, and even though we have apparently reached the peak of the second covid infection wave, it is not going to end completely in the year 2020 .

\section{References}

Fabiano, N. \& Radenović, S. 2020a. On COVID-19 diffusion in Italy: data analysis and possible outcome. Vojnotehnički glasnik/Military Technical Courier, 68(1), pp.216-224. Available at: https://doi.org/10.5937/vojtehg68-25948.

Fabiano, N. \& Radenović, S. 2020b. What could happen after the first wave of COVID-19 diffusion in Italy: learning from the 1918 influenza pandemic. Vojnotehnički glasnik/Military Technical Courier, 68(3), pp.413-423. Available at: http s://doi.org/10.5937/vojtehg68-26500.

-Ministero della Salute. 2020. Data of COVID-19 disease situation in Italy 2020 [online]. Available at: https://raw.githubusercontent.com/pcm-dpc/COVID-19/m aster/dati-andamento-nazionale/dpc-covid19-ita-andamento-nazionale.csv (in Italian) [Accessed: 18 November 2020].

Verhulst, PF. 1838. Notice sur la loi que la population suit dans son accroissement. Correspondance mathématique et physique, 10, pp.113-121 (in French). 
ВТОРАЯ ВОЛНА СОVID-19 2020 ГОДА В ИТАЛИИ: КРАТКИЙ АНАЛИЗ

Никола Фабиано ${ }^{a}$, Стоян Н. Раденович ${ }^{6}$

а независимый исследователь, Рим, Италия, корреспондент,

${ }^{6}$ Белградский университет, Машиностроительный факультет,

г. Белград, Республика Сербия

РУБРИКА ГРНТИ: 27.00.00 МАТЕМАТИКА:

27.29.00 Обыкновенные дифференциальные уравнения,

27.29.15 Общая теория обыкновенных дифференциальных уравнений и систем уравнений,

27.35.43 Математические модели в биологии

ВИД СТАТЬИ: оригинальная научная статья

Резюме:

Введение/цель: Основываясь на полученные ранее результаты, в статье проведен анализ второй волны инфекции Covid-19 и приведены некоторые прогнозы ее развития.

Методы: Для описания волны пандемии использовалась модель роста населения, дающая диффференциальное уравнеHue.

Результаты: Вторая волна заражения фрактически достигла своего пика в середине ноября 2020 года и в ближайшее время не уменьшится.

Выводы: В этом 2020 году вторая волна не закончится, поэтому нам придется подождать, когда наступит безопасное время и мы сможем вернуться к состоянию относительной нормальности.

Ключевые слова: коронавирус, COVID-19, диффреренциальное уравнение, соответствие данных.

ДРУГИ ТАЛАС ИНФЕКЦИЈЕ СОVID-19 U 2020. ГОДИНИ У ИТАЛИЈИ: КРАТКА АНАЛИЗА

Никола Фабиано ${ }^{a}$, Стојан Н. Раденовићб

а независни истраживач, Рим, Италија, аутор за преписку,

б Универзитет у Београду, Машински факултет, Београд, Република Србија 
ОБЛАСТ: математика

ВРСТА ЧЛАНКА: оригинални научни рад

\section{Сажетак:}

Увод/циљ: На основу претходно добијених резултата, анализиран је други талас инфекције COVID-19 и дата су нека предвиђања о његовој еволуцији.

Методе: Модел раста становништва који даје дифреренцијалну једначину коришћен је за описивање пандемијског таласа.

Резултати: Други талас инфекције налази се на врхунцу средином новембра 2020. године, и не очекује се да ће до његовог смањења доћи врло брзо.

Закључак: Други талас се неће завршити у 2020. години, па ће проћи извесно време пре него ито се вратимо у статус релативне нормалности.

Кључне речи: коронавирус, COVID-19, дифреренцијална једначина, уклапање података.

Paper received on / Дата получения работы / Датум пријема чланка: 19.11.2020.

Manuscript corrections submitted on / Дата получения исправленной версии работы / Датум достављања исправки рукописа: 21.12.2020.

Paper accepted for publishing on / Дата окончательного согласования работы / Датум коначног прихватања чланка за објављивање: 23.12.2020.

(C) 2021 The Authors. Published by Vojnotehnički glasnik / Military Technical Courier (http://vtg.mod.gov.rs, http://втг.мо.упр.срб). This article is an open access article distributed under the terms and conditions of the Creative Commons Attribution license (http://creativecommons.org/licenses/by/3.0/rs/).

() 2021 Авторы. Опубликовано в "Военно-технический вестник / Vojnotehnički glasnik / Military Technical Courier" (http://vtg.mod.gov.rs, http://втг.мо.упр.срб). Данная статья в открытом доступе и распространяется в соответствии с лицензией "Creative Commons" (http://creativecommons.org/licenses/by/3.0/rs/).

() 2021 Аутори. Објавио Војнотехнички гласник / Vojnotehnički glasnik / Military Technical Courier (http://vtg.mod.gov.rs, http://втг.мо.упр.срб). Ово је чланак отвореног приступа и дистрибуира се у складу са Creative Commons лиценцом (http://creativecommons.org/licenses/by/3.0/rs/).

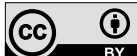

